\title{
Post-pandemic tourism resilience: changes in Italians' travel behavior and the possible responses of tourist cities
}

\author{
Fabio Corbisiero
}

Department of Social Sciences, University of Naples Federico II, Naples, Italy, and

Salvatore Monaco

Department of Education, Free University of Bozen-Bolzano, Bolzano, Italy and

Department of Social Sciences, University of Naples Federico II, Naples, Italy

\begin{abstract}
Purpose - Since the outbreak of COVID-19 in early 2020, the travel sector has faced an intense challenge, making tourism one of the most affected sectors at the time of writing. Based on the results of a survey administered to a sample of 700 Italian tourists, this paper aims to acquire an empirical understanding of key challenges for the travel and tourism sector in the coming months and the possible responses of tourist cities.

Design/methodology/approach - To study tourism after the pandemic, OUT (University of Naples Tourism Research Center) has created an online survey to answer the following questions: What will tourism be like after the pandemic? What will the main changes in travel behaviors be? What role will new information technologies play in future tourism? Are there territorial differences based on the spread of the virus?

Findings - The pandemic has inevitably affected everyone's tourist choices, regardless of how much their specific area of residence has been impacted by the virus. Consequently, it will significantly influence travelers' experiences. The Italian tourists who were survey respondents are aware that physical distancing rules will probably remain in effect for an extended time and, therefore, they cannot imagine future tourism not conditioned by these measures. This does not mean that Italians will give up tourism in the short-medium term, however. Indeed, the research data highlight the resilient character of tourism in that it is transformed but does not cease to exist.

Originality/value - By studying the future through a sociological approach, it is possible to identify how the COVID-19 emergency will impact tourism and how both the form and social meaning of mobility will be conditioned. On the basis of the data, the analysis will be directed from the present to the post-pandemic horizon, hypothesizing possible scenarios for the future of tourism and providing some possible policy indications.
\end{abstract}

Keywords Tourist behavior, Post-pandemic tourism, Sociology of the future

Paper type Research paper

(C) Fabio Corbisiero and Salvatore Monaco. Published by Emerald Publishing Limited. This article is published under the Creative Commons Attribution (CC BY 4.0) licence. Anyone may reproduce, distribute, translate and create derivative works of this article (for both commercial and noncommercial purposes), subject to full attribution to the original publication and authors. The full terms of this licence may be seen at http://creativecommons.org/licences/by/4.0/legalcode

Authors would like to acknowledge all the colleagues of OUT (Osservatorio Universitario sul Turismo) in the Departments of Social Science at University of Naples Federico II.

Authors are grateful to Rosanna Cataldo, Gabriella Grassia and Pietro Maturi for their support and inspiring suggestions.
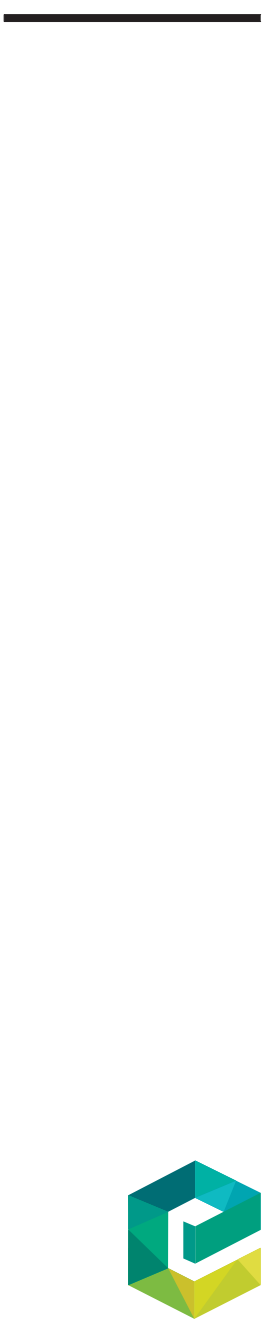

.


WHATT

13,3

\section{Introduction}

What will travel look like post-coronavirus and how can we try to support an industry that has been on its knees since the pandemic began in early 2020? The answers to these questions are still uncertain and the lessons we are learning from this painful historical moment are different. Nothing can be taken for granted and multiplying opportunities, travel arrangements and technological solutions is not enough to guarantee solid growth prospects for tourism. Tourism, despite the support of new technologies (apps, artificial intelligence, augmented reality, big data...), constitutes a complex and therefore fragile system, as it depends on multiple factors such as human well-being and the environment, mutual trust, international solidarity, security, peace and health.

COVID-19 has significantly impacted two of the main elements that distinguish tourism, namely, physical travel and social interactions. As a result, many restrictions and extraordinary precautionary measures have been implemented internationally to stem and combat the coronavirus pandemic. These initiatives have completely overturned the daily life of people on a global level, including by exerting a powerful impact on their tourist behavior (Corbisiero, 2020; IPSOS, 2020; Irwin, 2020). Thus, the coronavirus pandemic temporarily halted the growth of tourism, a sector that was experiencing a real boom in recent years (UNWTO, 2019; Cerved, 2019; RTE, 2020; WTTC, 2020a).

Within urban contexts, the COVID-19 affected all parts of the hospitality value chain. The impact of the pandemic cancelled daily events such as catering or relax services, closed accommodations and shut down attractions became immediately felt within the tourist chain. Bars, pubs and restaurants had to close as well, though in several countries, a switch to takeaway/delivery sales allowed some areas to continue to turn the economy (Gössling et al., 2020).

Widely, cities are impacted even in situations where they have escaped the worst of the health crisis itself.

Since the advent of the coronavirus, the transportation system and, more generally, social mobility as well have suffered a setback not only because of travel bans and widespread restrictions on physical gatherings, but also because they immediately suffered from negative perceptions owing to the fear of contagion. With mobility at a standstill - cruising ships and aircraft parked - collapsing consumer demand, low cash reserves, hotels shuttered, it took only a few weeks for the pandemic to completely disrupt the geography of travel and tourism (Florida, 2020). As reported by Haywood (2020), "Destinations reliant on tourism became ghost towns. Cries of 'What's going on?' led to feelings of sheer hopelessness among many, dramatized by 'Inner City Blues' (Marvin Gaye songs on YouTube)” (p. 599).

It should be specified that tourism demand has slowly begun to rise again in several European countries in the second half of 2020 (UNWTO, 2020b). A pretty safe and responsible travel is currently possible through European countries, and it is imperative that governments work closely to get tourism moving again.

A trend that makes the resilience of the tourism processes evident, also in regard to other ongoing crises that are not as immediate, but equally meaningful as COVID-19, such as ecological footprints or landscapes conservation related to leisure tourism. The link between resilience and tourism destinations is a significant issue because disturbances are not exclusively connected to pandemics, but several further shocks have been on the debating table for a long time. Climate changes, terrorist attacks, financial and industrial crisis and digital divide have to be seriously considered as "tourist shocks" owing to their effects on tourist communities to survive (Araña and León, 2008; Lee and Chen, 2011). As a deceptive "magic recipe" to build a discourse about post-pandemic tourism, resilience introduces controversial aspects that are often related to sustainability or patched up by coupling the term "tourism" with the adjectives "green," "sustainable" or "slow." In our paper, we will 
focus on the fact that tourism would be able to bind to the notion of sustainability, at least in its definition of ability to preserve something in existence without interruption or diminution (Assadourian, 2013). The comprehension of the dynamics of economic and social crises suggests new thinking on the re-design of tourism and of its connected social needs. Particularly, in the aftermath of the COVID-19 emergency travel-as-usual will no longer be sustainable, with impacts on both the environment and local communities, and sometimes even without significant economic benefits (Tembo, 2020). For a general destination to be resilient, to resist and to adapt to external disruptions, one basic condition is to respond to, cope with and adapt to changes over time without losing its fundamental structure and function (Adger et al., 2002). For sure the resilience depends also on the characteristics of the disaster, the level of exposure of the system and its sensitivity as well as the adaptation that results from the territorial response (Becker and Rubinstein, 2004; Cochrane, 2008). In this sense, in considering the relationship between resilience and tourism, the role of the tourists' communities, the type of shock and the ability to adapt and persist in its business activities must also be analyzed (Ivkov et al., 2019). After each crisis, there is an increase in fear, tension and confusion as tourist behavior is sensitive to crises (Bodosca et al., 2014).

The purpose of this paper is to obtain an empirical understanding of the key challenges for the travel and tourism sector in the coming months. Predictive analysts (Barlow et al., 2016; Corbisiero et al., 2020; Lade et al., 2020) have long underlined the role of "anthropogenic disasters" in the future of tourism, disasters characterized by human interference in the natural environment. Therefore, to identify what impact the pandemic is having and will have on the future of tourism, OUT (University of Naples Tourism Research Center) has conducted an online survey specifically aimed at detecting the behavior, intentions and future propensities of Italian travelers. Because of the highly interlinked cultural, political and socio-economic impacts of COVID-19, historical trends of tourism are expected to be modified. The predictive power of traditional explanatory models about tourist dynamics (Röcker, 2010) might not be appropriate anymore because of the new pandemic. So the future models need to focus on taking more novel approaches for exploring the essential factors there are behind the acceptance to return travelling safely.

More specifically, the empirical study was conducted to understand the sensitivity of Italian tourists faced with a health crisis such as that of COVID-19, with the aim of obtaining information from the travelers' community to identify any potential changes in their travel behaviors as a consequence of COVID-19. The evolution of these behaviors has also been studied from a temporal perspective. Our main hypothesis is that through a comparison between pre-pandemic behaviors and predictable future behaviors the disruption owing to the present crisis can be converted into transformative innovation and help reshape and rethink the tourism, establishing a new way to travel in terms of a system which is commercially viable and offers the community of tourists equitable and sustainable access to tourism resources and distribution of the benefits, while minimizing negative environmental and other impacts.

The Italian case is an interesting focus for sociological study about tourism because Italy's hospitality industry was the first in Europe to be hit by the devastating impact of the virus and to transition through the various phases of COVID-19 containment measures, including the shock of lockdown (Monaco, 2020). In Italy, the spread of the virus has varied greatly among geographical areas (Corbisiero and La Rocca, 2020). Although the virus ended up reaching all the regions of the peninsula, the country's north has been the most affected area since the beginning of the pandemic. Lombardy (where the first major hotbed of the epidemic in Italy was discovered) has been the most heavily struck region, with tens of thousands of infected individuals and thousands of deaths. The other neighboring Italian 
WHATT

13,3

404 regions most powerfully impacted have been Veneto and Emilia-Romagna. On the basis of these considerations, the study also seeks to understand if there are differences among Italians' visions of and intentions for the future of tourism based on their area of residence.

By studying the tourism through a territorial approach, it is possible to identify how the COVID-19 emergency will impact tourism and how mobility and the tourist accommodation will be conditioned both in their form and social meaning. In our perspective, the space over which a COVID-19 impact analysis needs to be defined goes beyond geographical boundaries and includes multiple dimensions of the physical and virtual realities within which the "tourism gaze" (Urry and Larsen, 2011) plays out. Some cities in Italy are facing the complex challenge of the reorganization of cultural offer, mobility and accommodation, where the gradual reopening involved the resumption of some tourist activities and the consequent increase in related mobility flows.

\section{Methodology}

Research instrument

As part of this study, a questionnaire was designed to collect data from a sample of Italian travelers, holders of a long-term residence in Italy. The questionnaire was divided into five sections.

The first section was designed to collect the socio-demographic data of tourists, including residence area, gender, age, nationality, income, education level and occupation.

The second section of the questionnaire comprises a series of questions aimed at learning about Italians' tourist habits before the health emergency. More specifically, respondents were asked to indicate their preferred means of transport, trip duration, the type of accommodation they mainly chose and their favorite travel companions.

The same questions were asked again in the third section of the questionnaire, this time from a forecasting point of view. In other words, travelers were asked to indicate their tourist preferences for these same aspects but imagining their next trips in the post-COVID period.

The fourth section of the questionnaire was implemented to understand the main consequences for the tourism sector in the short-medium term. To obtain this information, a set of questions on travelers' needs, fears and expectations was proposed.

In the last section of the questionnaire, a specific space was dedicated to the use of new technologies, both in everyday practice and as tools for increasing possibilities in tourism, including through virtual travel.

\section{Population and sample method}

The research was carried out on a sample of Italian residents. For the survey, a subpopulation made up of individuals aged between 15 and 75 years old was chosen, as it was important that the sample include only people who will actually be capable of engaging in tourism autonomously in the near future. Not having a list of subjects to be involved in the research, the sampling method used was non-probabilistic. To ensure the geographical representativeness of the data, the working group chose to set up sampling by quotas, dividing the sample into small groups proportional to the distribution of the Italian population among the three main available tourist areas in Italy: north, center and south.

The questionnaire was computerized via QUALTRICS and disseminated online through the main communication channels of OUT (social networks, websites and mailing lists). Thus, the data was collected online between March and August 2020.

We are aware that the results of random sampling research are not representative in that the insights and observations they produce cannot be extended in all respects to the entire 
population group (Lombi, 2015; Monaco, 2019). However, we believe that the now widespread use of the internet among the Italian population allowed this study to reach heterogeneous targets which, as such, are also able to provide a highly reliable general picture of social phenomena (Mahrt and Scharkow, 2013). In addition, the statistical significance of the collected data on changes from pre-COVID to post-COVID has been realized using the chi-square test.

\section{Results}

The group of 700 subjects included in the sample has an average age of 38 years and is made up of $60 \%$ women and $40 \%$ men. Respondents are mainly office workers (38.3\%) and students $(29.9 \%)$, with $10.1 \%$ of the survey respondents unemployed and/or seeking employment.

The educational status of the Italian tourists involved is quite high, with over $63.5 \%$ of them holding a post-secondary degree. The male participants have a higher education level than the female survey respondents: $40 \%$ of the Italian men involved in this study have an undergraduate post-secondary degree, and $27.6 \%$ a postgraduate degree. By comparison, $37 \%$ of the female travelers involved have an undergraduate post-secondary degree and $27 \%$ a postgraduate degree.

Almost all of the sample (93\%) declared that their tourist habits will change following the most acute phase of the health emergency in relation to: the duration of tourist experiences, travel companions, type of accommodation, means of transport chosen and use of technologies. Delving deeper into the data, it is immediately clear that this anticipated change is a widespread trend at the national level, but the propensity for such change is expressed more emphatically by respondents residing in the regions of northern Italy that have been most affected by the pandemic: $95 \%$ of people living in the north of Italy said that will change their tourist habits, versus $92 \%$ of central residents and $89 \%$ of people living in the south. One initial empirical finding of interest is that the pandemic has inevitably affected everyone, regardless of their area of residence.

What respondents said in general was confirmed by a comparison with their answers to the questions in Sections 2 and 3 of the questionnaire, through which it is possible to compare pre- and post-COVID-19 tourist habits and preferences.

As can be seen from Table 1, the Italian survey respondents who declared that they do not intend to give up tourism in the future plan to engage in shorter experiences than before:

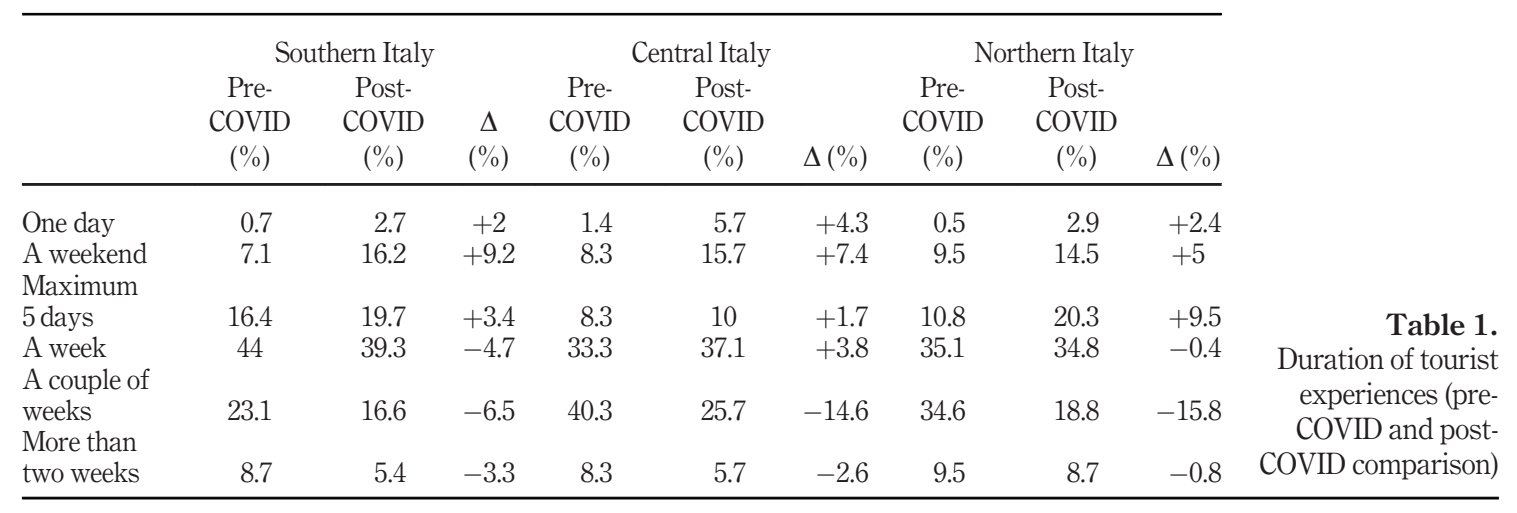

Post-pandemic tourism resilience

405 
WHATT

13,3

406

generally speaking, trips lasting longer than a week lose their appeal in favor of microvacations.

More specifically, a geographical breakdown of the responses shows a certain caution on the part of residents of southern Italy. As compared to the pre-COVID period, they are more inclined to concentrate their tourist experiences in the space of a few days or no more than five days. Survey respondents who reside in central Italy are likewise willing to give up a few days of vacation, but the number of people who decide to stay away from home for at least a week is higher. As for northern Italians, many them continue to prefer holidays of at least seven days, but the percentage of people who spend two weeks away from home is clearly decreasing.

Another interesting change in the intentions of Italian travelers has to do with travel companions. In Table 2 we can see that Italian tourists intend to take fewer trips with friends or organized groups and to engage in more tourist experiences with partners and family, most likely because these latter are people with whom they already share a certain degree of intimacy in everyday life and who they trust more. This attitude is also explained by the fact that the Italian government's regulations during the lockdown period permitted people to visit family members first and foremost, and non-relatives only in a later phase.

In other words, the research highlights that respondents are adopting a prudent approach to the choice of travel companions, a trend that is widespread nationally and most evident among northern respondents. In terms of travel companions, in general it could be argued that the Italians who took part to the survey prefer to engage in tourism with people whose behaviors, health status and daily encounters they know well (or believe they know well).

With respect to this specific aspect, the greatest degree of caution is displayed by over40s: a higher percentage of them declared that they prefer planning their holidays with family as compared to members of the younger generations. In contrast, young people from southern Italy in particular still consider the experience of travel as a moment of sharing with their group of friends. Moreover, we can see that the trend of taking solitary trips remains quite unchanged in the center and south of Italy. This type of travel is also practiced almost exclusively by the youngest male respondents in the sample.

As regards choice of accommodations (Table 3), from a forecasting point of view and in light of physical distancing measures, in general the subjects show greater interest now than in the pre-COVID period in holiday homes (where they can personally oversee the cleaning of rooms and spaces) and hotels rated four stars and up. Luxury hotels are acquiring

Table 2.

Travel companions (pre-COVID and postCOVID comparison)

\begin{tabular}{|c|c|c|c|c|c|c|c|c|c|}
\hline & \multicolumn{3}{|c|}{ Southern Italy } & \multicolumn{3}{|c|}{ Central Italy } & \multicolumn{3}{|c|}{ Northern Italy } \\
\hline & $\begin{array}{l}\text { Pre- } \\
\text { COVID } \\
(\%)\end{array}$ & $\begin{array}{l}\text { Post- } \\
\text { COVID } \\
(\%)\end{array}$ & $\begin{array}{c}\Delta \\
(\%)\end{array}$ & $\begin{array}{l}\text { Pre- } \\
\text { COVID } \\
(\%)\end{array}$ & $\begin{array}{l}\text { Post- } \\
\text { COVID } \\
(\%)\end{array}$ & $\begin{array}{c}\Delta \\
(\%)\end{array}$ & $\begin{array}{l}\text { Pre- } \\
\text { COVID } \\
(\%)\end{array}$ & $\begin{array}{l}\text { Post- } \\
\text { COVID } \\
(\%)\end{array}$ & $\begin{array}{c}\Delta \\
(\%)\end{array}$ \\
\hline With the family & 24.9 & 28.7 & +3.7 & 16.7 & 20 & +3.3 & 24.3 & 31.4 & +7.1 \\
\hline $\begin{array}{l}\text { friends } \\
\text { With an } \\
\text { organized }\end{array}$ & 34.5 & 25.8 & -8.8 & 20.8 & 14.3 & -6.5 & 24.3 & 15.7 & -8.6 \\
\hline $\begin{array}{l}\text { group } \\
\text { In pairs }\end{array}$ & $\begin{array}{c}2 \\
33.5\end{array}$ & $\begin{array}{r}1.3 \\
39.6\end{array}$ & $\begin{array}{l}-0.7 \\
+6.2\end{array}$ & $\begin{array}{r}6.9 \\
47.2\end{array}$ & $\begin{array}{r}1.4 \\
57.1\end{array}$ & $\begin{array}{l}-5.5 \\
+9.9\end{array}$ & $\begin{array}{r}4.1 \\
43.2\end{array}$ & $\begin{array}{l}1.2 \\
50\end{array}$ & $\begin{array}{l}-2.9 \\
+6.8\end{array}$ \\
\hline Solo travels & 5.1 & 4.6 & -0.5 & $\begin{array}{r}8.2 \\
8.3\end{array}$ & 7.1 & -1.2 & 4.1 & 1.7 & -2.3 \\
\hline
\end{tabular}




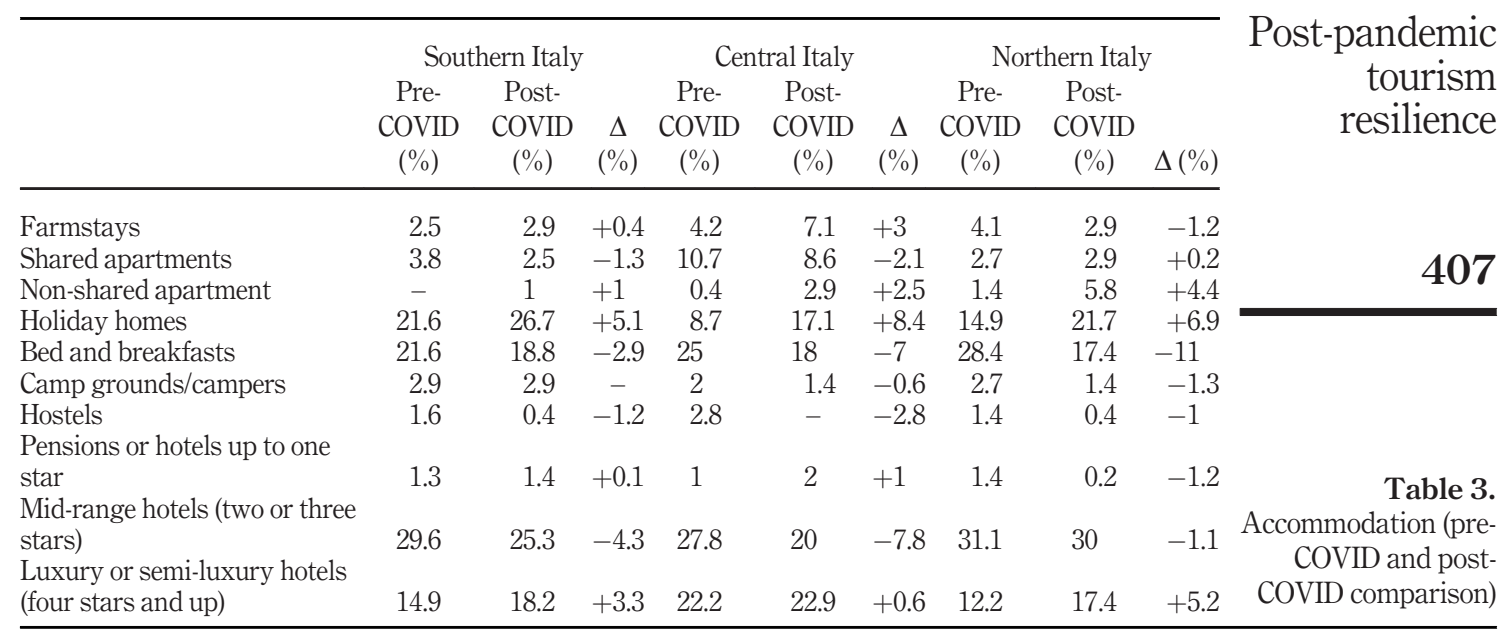

growing interest in the eyes of Italians as they are equipped with rooms or suites featuring large spaces.

Moreover, it is important to underline that sharing economy practices, which were experiencing an interesting period of growth in recent years (Cheng, 2016; Hamari et al., 2016; Ertz et al., 2019), are undergoing a setback. Interpreting the data from a territorial perspective as well, we can also argue that, before COVID, it was mainly respondents residing in central Italy who chose to stay in shared apartments. The advent of the pandemic seems to some extent to be discouraging this practice, as well as that of staying in camp grounds or hostels (no respondents from central Italy stated that they would consider a hostel as a possible accommodation in the short-long term).

As we anticipated, Italian tourists who have more extensive economic resources expressed a greater preference for expensive accommodation facilities than other respondents. This group includes mainly older people residing in northern Italy. They prefer to spend their time in luxury hotels because these facilities have the spending capacity to offer their guests the best guarantees regarding the cleanliness of the spaces as well as customer check-in and check-out procedures.

A final aspect we investigated to monitor the tourism changes of Italians from the preCOVID to the post-pandemic period is the choice of means of transport for traveling. It is often argued that a country with a good transportation system can be considered to be a tourist destination (Das et al., 2007; Pagliara et al., 2017). Thus, according to Kaul (1985), the transportation network is one of the most fundamental components of successful tourism development. Nevertheless, in line with recent data that testify to the crisis that the transport system has been undergoing for several months now (Unimpresa, 2020), the data in Table 4 clearly show that a significant percentage of Italians avoid traveling by plane, train or bus. The fact that it is not always easy to comply with rules regarding appropriate interpersonal distances and the exorbitant prices of airline and high-speed train tickets have driven many Italians to prefer car travel to reach tourist destinations. In the south in particular, more so than other areas of Italy, the data show substantial interest on the part of respondents in the possibility of renting a car for excursions. One of the positive aspects of traveling by car is undoubtedly avoiding the risk of coming into contact with unknown 


\begin{tabular}{|c|c|c|c|c|c|c|c|c|c|c|}
\hline \multirow{4}{*}{$\begin{array}{l}\text { WHATT } \\
13,3\end{array}$} & & & & & & & & & & \\
\hline & & \multicolumn{3}{|c|}{ Southern Italy } & \multicolumn{3}{|c|}{ Central Italy } & \multicolumn{3}{|c|}{ Northern Italy } \\
\hline & & Pre- & & & Pre- & & & Pre- & & \\
\hline & & $\begin{array}{c}\text { COVID } \\
(\%)\end{array}$ & $\begin{array}{c}\text { Post- } \\
\text { CovID (\%) }\end{array}$ & $\begin{array}{c}\Delta \\
(\%)\end{array}$ & $\begin{array}{c}\text { COVID } \\
(\%)\end{array}$ & $\begin{array}{c}\text { Post- } \\
\text { COVID }(\%)\end{array}$ & $\begin{array}{c}\Delta \\
(\%)\end{array}$ & $\begin{array}{c}\text { COVID } \\
(\%)\end{array}$ & $\begin{array}{c}\text { Post- } \\
\text { CoVID (\%) }\end{array}$ & $\begin{array}{c}\Delta \\
(\%)\end{array}$ \\
\hline \multirow{3}{*}{408} & Airplane & 24 & 20.4 & -3.6 & 25.7 & 18.5 & -7.2 & 23.8 & 18.3 & -5.5 \\
\hline & Train & 23.7 & 18.9 & -4.8 & 25 & 20.5 & -4.5 & 21.8 & 17.8 & -4 \\
\hline & & 11.2 & 6.7 & -4.5 & 9.9 & 8.0 & -1.9 & 10.1 & 6.6 & -3.5 \\
\hline \multirow{3}{*}{$\begin{array}{l}\text { Table } 4 \text {. } \\
\text { Means of transport } \\
\text { (pre-COVID and post- } \\
\text { COVID comparison) }\end{array}$} & $\begin{array}{l}\text { Private } \\
\text { car }\end{array}$ & 21.0 & 28.3 & 7.3 & 21 & 30.5 & 9.5 & 24.2 & 32.5 & 8.3 \\
\hline & $\begin{array}{l}\text { Rented } \\
\text { car }\end{array}$ & 7.4 & 13 & 5.6 & 7.9 & 11.5 & 3.6 & 11.7 & 15.7 & 4 \\
\hline & $\begin{array}{l}\text { Snip or } \\
\text { ferry }\end{array}$ & 12.7 & 12.8 & 0.1 & 10.3 & 11 & 0.7 & 8.5 & 9.1 & 0.7 \\
\hline
\end{tabular}

individuals. Moreover, even if this means of transport makes the journey longer and more tiring, it also allows people to make stops along the way, offering them the chance to discover places that they otherwise would only have been passing through.

The subjectivity of distance and proximity plays an important role in the spatial distribution of tourists, destinations and tourist activities (Larsen, 2015). The distance to and proximity of destinations influence which places tourists view as attractive and which are perceived as unattractive to visit. This is particularly informative in the context of the pandemic.

The most recent international data on tourism mobility (UNWTO, 2020a) describe a scenario in which tourists choose destinations that are closer to their usual places of residence, not only because several international destinations remain inaccessible but also because nearby destinations are considered less risky and they allow people to return home quickly in case of need or emergency.

To support our results we used a series of chi-square tests. As the $p$-value is less than our chosen significance level $(\alpha=0.05)$ for all the analyzed dimensions, we can reject the null hypothesis and reveal statistically significant difference between the analyzed aspects from pre-COVID 19 and post-COVID 19 in the behavior of Italian tourists (Tables 5-8).

Table 5.

Independence test (chi-square) for duration of tourist

$\begin{array}{ll}\text { Table 6. } & \text { Chi-square (observed value) } \\ \text { Independence test } & \text { Chi-square (critical value) } \\ \text { (chi-square) for travel } & \text { Degrees of freedom } \\ p \text {-value } \\ \text { companions } & \text { Alfa }\end{array}$

$1,062,484$

43,773

30

$<0.0001$ 0.05 
Such significance points to a clear shift in the future of tourism, not only for Italy but also in other countries.

To better understand the changes in travel behaviors, in the following sections of the questionnaire we focused on the most significant tourists' attitudes and fears and their future use of technology in relation to tourism. In total $82.62 \%$ of subjects stated that they prefer tourist destinations with large open spaces while $66.7 \%$ declared that they avoid the destinations more heavily affected by the coronavirus. In this sense, according to the group of respondents, mountain areas, but also countryside and natural parks, have a significantly competitive advantage. Looking to the future once again, $60 \%$ of respondents said they will avoid urban tourism and tourist cities, reflecting their awareness that the virus has spread more widely in urban contexts (Bachimon et al., 2020).

Many cities have lost a part of their appeal in the eyes of Italians, especially in the central-northern part of the country. This change was already visible during the summer of 2020, when Venice, Milan, Genoa and Rome itself (to name just only the best-known examples of central-northern Italian tourist cities) welcomed fewer visitors than they had in previous years, which made them appear as strangely empty and silent as several other cities around the world (Ioannides and Gyimóthy, 2020). The same fate has not affected southern Italian tourist cities such as Naples or Palermo, which have hosted mainly internal tourism. Although the emergency has diminished, the image of hotbed is still associated with urban contexts in the collective imagination, owing in part to mass media communication that has long emphasized the role of cities in the spread of the virus (Antonelli, 2020; Cowper, 2020; Yu et al., 2020). This concern mainly has an emotional impact on people living in areas that have been less directly affected by the pandemic. It is no coincidence that respondents residing in Lombardy, Veneto, but also Trentino AltoAdige and Emilia Romagna (areas that experienced moments of great difficulty, especially in the initial phase) expressed themselves less in agreement with this statement. From a sociological point of view, this data reveal an emerging prejudice amongst Italians toward the areas in which a greater number of cases have been recorded based on the fear, albeit unfounded, that the risk of contagion remains high even after the emergency has passed.

In addition, $69 \%$ of the sample said that they dread meeting people from other cities for fear of contagion. This data allows us to argue that, in the current historical and social context torn apart by the COVID-19 pandemic, one social consequence is that foreigners are kept at a distance by locals in pursuit of an idea of safety and the hope of preserving their health. This phenomenon contradicts one of the cornerstones of post-modern tourism: the

Chi-square (observed value)

Chi-square (critical value)

Degrees of freedom

$p$-value

Alfa

Post-pandemic

tourism resilience

409

\section{$-$}


WHATT

13,3 encounter with the other, mutual contamination, coming to know cultures other than one's own through dialogue and exchange with the people who live in other contexts (Murji and Picker, 2020; Noor et al., 2020; Page and Connell, 2020).

As for the role of new technologies in the future of tourism, new technological applications such as the Internet, mobile-based interfaces or augmented-reality systems constitute significant pillars in tourists' choices. In the pandemic era, the link between tourism and technologies would seem stronger than ever owing to the acceleration of mobility that the latest generation of technological services seems to offer. Examples are digital identification technology, used not only to expedite reception services but also to make transits quicker, and virtual tours of museums.

According to our data, $47 \%$ of respondents stated that they had engaged in forms of virtual tourism during the three months prior to the survey. The highest percentage of virtual travelers is concentrated in northern Italy $(58.3 \%)$ and is mainly made up of young people belonging to the Millennial generation and Gen Z. Although virtual tourism through online photos or videos, Google Maps, Google Street View, 3D reproductions and videogames seems to have become quite widespread in Italy, only $6.7 \%$ of respondents said that they agree with the idea that virtual tourism can supplant physical travel.

Conversely, as people are living increasingly digital and connected lives, it seems that enjoying physical experiences while traveling is the only (or at least the primary) way to unwind. However, the participating sample agrees in attributing substantial weight to technologies in the post-COVID period. More than in the past, they are considered as useful devices for leading a life in greater safety and with more opportunities. Their usefulness is recognized above all in booking and making online purchases $(76 \%)$, searching for tourist information, and receiving constant updates on the evolution of the epidemic (81.4\%). An interesting finding is the idea, more common among the youngest respondents of the sample, that robotics and artificial intelligence could be useful tools for limiting the possibility of contagion among people (15\%).

\section{Discussion}

The COVID-19 emergency represents a watershed between what tourism was like a few months ago and what it will be like in the coming years. The survey highlights that the behavior of Italian tourists is and will be influenced for quite some time by a series of factors including personal economic well-being, changes in costs, perceived health risks and consumption capacities that have changed as a result of pandemic restrictions. The Italian tourists in our sample are aware that physical distancing rules will probably remain in effect for a few years and, therefore, they cannot imagine future tourism not conditioned by such measures. This does not mean that Italians will give up tourism in the short-medium term. Indeed, the research data highlight the resilience of tourism, a field that is transformed but does not cease to exist (Jeuring and Diaz-Soria, 2017). Our research found that respondents indicate a general preference for more nearby vacations, historically associated with lower sociodemographic status and older age brackets (Berrino, 2011).

It is not the first time in the history of tourism that mobility has been challenged by epidemics.

In the new century, an anxiety of travel conditioned by fear of contagion arose as early as 2002, the year in which alarm began to spread about SARS, that was an atypical form of pneumonia that first appeared in Guangdong province (Canton) in China. In 2009, there was also the so-called "Swine Flu," caused by an A H1N1 virus, which triggered enormous concern globally. The Middle East respiratory syndrome appeared in 2015 (Gostin and Lucey, 2015). 
As we have seen, although the magnitude of these catastrophic events could have generated a permanent blockage of tourist flows, none of them ultimately caused a significant long-term decline in global tourism development. In all of these circumstances, tourism displayed its resilient character, proving itself a sector capable of resisting critical circumstances. It has certainly undergone variations and modifications each time, from the destinations people choose to the way they practice tourism (Jeuring and Haartsen, 2017), but it has always survived, establishing itself as one of the most successful sectors.

The results of this study suggest that the same process will occur in the post-COVID

Post-pandemic tourism resilience

phase as well. The losses caused by this pandemic have not put an end to the desire to escape and travel, so Italian travelers will continue to engage in tourism, albeit differently than in the past in terms of places to visit, time spent, accommodation facilities, travel companions, the use of technology and so on.

These considerations are also based on the data we collected regarding the use of new technologies. Tourists have stated that they find technologies extremely useful to support their tourism choices and during their travel experiences, but at the same time they have stressed that virtual travel alone is not enough to satisfy their desire for mobility. Although there have been many advances in technology, our sample does not consider virtual reality and augmented reality as valid alternatives to real travel.

As de Kerckhove suggests (Marino, 2020), we can distinguish "tourism of the mind" from "tourism of the body." The first category includes imaginative and virtual travel (Urry and Sheller, 2006). These experiences are a useful tool for gaining knowledge about the world or for visiting otherwise-inaccessible places (Monaco, 2018). During the first national lockdown, for example, people practiced mind tourism on a massive scale because they could not do otherwise. However, the research data show that it is "tourism of the body," enacted through physical mobility, that constitutes the element which will prove capable of overcoming the obstacles to tourism. Italian travelers seek these experiences out to have a direct relationship with places and objects. In other words, the pandemic has increased and accelerated the use of new technologies also to practice alternative forms of tourism. In this sense, new technologies have made it possible to overcome the obstacles linked first to quarantine and then to physical distancing measures. However, this seems to have not been enough for Italian travelers. In fact, as soon as they had the opportunity to travel again, they abandoned the means of communication to experience a non-mediated contact with the world. In this scenario we can see how once again tourism has already begun to show its resilient feature, thanks also to the ability of its protagonists to invent and reinvent it, in a form that inherits something from the past, but at the same time adds new elements.

Looking at the future, in this scenario, local communities should be considered as important partners for the restart of tourism in each territory. They must be particularly involved in designing authentic and engaging types of experiences for travelers interested in discovering local beauties. An innovative solution could be to create networks amongst the public sector, private tourist companies and local communities, so as to work synergistically for the territorial revaluation and development of a new form of tourism, in line with the new needs expressed by the tourist demand.

The behavior of local communities, which can encourage a different form of tourism, and the new choices of tourists, adapted to the new social, historical and health contingencies, may seem ambiguous. But it is precisely in this ambiguity that we can clearly see that traveling is a social need: even if on the one hand it frightens people, on the other hand it is perceived as a necessity.

According to recent studies on this issue (OCSE, 2020; Lapointe, 2020; Vishal and Aakriti, 2020), the will to travel expressed by the Italian people included in the survey, despite the 
WHATT

13,3

difficulties characterizing the current moment, is probably based on four short-term expectations: the vaccine efficacy, the reduction of travel restrictions, the metabolization of health measures for travelers and passengers and, above all, the spread of local tourism. In particular, the tourists involved in this study currently appear to be oriented more than ever toward forms of proximity travels within confined areas not far from home during which they avoid crowds as much as possible. From this analytical point of view, it is safe to argue that journeys will increasingly focus on "why" to visit rather than "what" as in the past, to meet travelers' specific needs to go beyond sterile or already-familiar experiences. Recent research on the subject shows how these considerations do not only apply to Italian tourists, but can also be extended to other travelers around the world. For example, in the postCOVID, the demand for domestic tourism in the United Kingdom has registered an unprecedented rise (Dinev, 2020). There too, as in Italy, travelers have not abandoned the desire to travel, but have oriented their choices toward closer destinations. As recently stated by the World Travel and Tourism Council (WTTC, 2020b), a similar situation also marks other territories, including European countries such as Spain, Greece, France and Portugal among others. There traveler preferences and behaviors have shifted toward domestic and regional vacations and the outdoors will reign in the short-term, with a specific attention to health, safety and social, and environmental, sustainability.

\section{Conclusions and implications}

The health, social and economic emergency produced by COVID-19 is offering tourist operators the opportunity to rethink their range of proposals in a more sustainable and higher-quality way and the opportunity for travelers to rethink the way they enjoy their holidays.

The current crisis could thus represent an important moment for pursuing the kind of pathways of tourist innovation already foreseen by Italy's 2017-2022 national tourism strategic plan, pathways with the capacity to guide local and national growth. Precisely in light of the current situation, some scholars (Kozul-Wright and Barbosa, 2020; Rab and Kettler, 2020; Sigala, 2020) have already called for taking advantage of this period of interruption to make wide-ranging structural changes to the tourism sector, starting with a renewed reflection on several aspects of sustainability policy. In fact, the research data on the habits and expectations of Italian tourists suggest that an alternative to the mass tourism model is possible. Future tourism could be zero kilometer and "slow." These are niche phenomena that had already begun to take hold in recent years (Hall, 2006; Nilsson et al., 2011), attracting people interested in more intimate tourism, in the open air and in contact with nature, away from the masses and frenetic pace of the city (Moralli and Allegrini, 2020; Seraphin and Dosquet, 2020).

Although it is difficult to observe the situation from such a perspective in this moment of serious crisis, the historical and social moment may lend itself to repositioning and redeveloping places and structures of the territories of tourism, bringing them more in line with international criteria of sustainability, ethics and aesthetics. However, to make such a move possible, it is necessary to reallocate resources, mitigate the overtourism of certain places, invest in environmentally responsible ways and care for people and local areas.

In this situation, even Italian urban centers can benefit from the uncertainty of this historical period: the drop in arrivals will be inevitable, especially as much of the foreign component will be missing, but there could instead be an increase in tourists from nearby areas, once again following local itineraries or in any case at short range (Milano et al., 2019).

This scenario represents an opportunity for local areas to identify new and more sustainable ways of welcoming and managing tourist flows. In other words, starting from 
the current situation of undertourism, cities have the opportunity to reformulate their range of tourist offerings according to a sustainable perspective (La Rocca, 2013; Papa and Fistola, 2016).

Also the hospitality sector, including museums, galleries and attractions, has to imagine

Post-pandemic tourism resilience a structural change in the tourist offer. Most likely not all businesses will survive the crisis. Companies that intend to endure should take action immediately to identify the most suitable strategies to reassure the new tourist demand, responding to the needs of travelers in an appropriate manner.

As the recovery of international tourism is likely to be slow, the hospitality sector could benefit from domestic demand, as residents currently prefer to forego overseas holidays for domestic holidays.

However, even in response to the economic crisis that has affected many workers, the hospitality sector should be not only more attractive, but also economically viable and competitive.

Last but not least, we have seen that safety and hygiene have become key factors to select destinations and tourism activities. This must be an important lesson from which to start re-imagining and reviewing the specific company policies. In addition, tourist destinations and businesses should prioritize younger travelers, who at this moment seem to be the least frightened of the virus, probably also because of the fact that the average age of the victims of the pandemic is very high (Goldstein and Lee, 2020; Boehmer, 2020).

They must create the right product offerings and promote them on the most appropriate communication channels, especially using the online ones.

The uncertain period requires transparency in communication. For this reason, another incentive could be to ensure the greatest possible clarity on cancellation and refund policies in case of critical situations or in the face of unexpected travel restrictions.

Tourists will be able to learn to adapt to the unpredictability of post-COVID tourism only if companies also demonstrate that they are the first to be flexible to change.

A final consideration concerns the areas that have been most affected by the pandemic in the past few months and which, despite having moved past the emergency phase, are victims of an emerging prejudice powered by the fear that these places may still harbor the virus. These sites must work to identify specific territorial marketing and place branding strategies capable of freeing them from the image of continuing danger. In this regard, it might be useful to accompany any initiative with both epidemiological data on the rate of infections and evidence of the safety measures that have been adopted on-site.

\section{References}

Adger, W.N., Kelly, P.M., Winkels, A., Huy, L.Q. and Locke, C. (2002), "Migration, remittances, livelihood trajectories and social resilience", Ambio: A Journal of the Human Environment, Vol. 31 No. 4, pp. 358-366.

Antonelli, F. (2020), "Emerging aspects in technocratic politics at the time of the SARS COVID 19 crisis”, Rivista Trimestrale di Scienze Dell'Amministrazione, Studi di Teoria e Ricerca Sociale, Vol. 2, pp. 1-20, doi: 10.32049/RTSA.2020.2.13.

Araña, J. and León, C. (2008), "The impact of terrorism on tourism demand", Annals of Tourism Research, Vol. 35 No. 2, pp. 299-315.

Assadourian, E. (2013), State of the World 2013, Island Press, Washington, DC.

Bachimon, P., Eveno, P. and Gélvez Espinel, C. (2020), "Primary and secondary place of residence, the digital link and the rise of presence", Worldwide Hospitality and Tourism Themes, Vol. 12 No. 4, pp. 369-385. 
WHATT

13,3

Barlow, J., Lennox, G.D., Ferreira, J., Berenguer, E., Lees, A.C., Mac Nally, R., Thomson, J.R., de Barros Ferraz, S.F., Louzada, J., Oliveira, V.H.F. and Parry, L. (2016), “Anthropogenic disturbance in tropical forests can double biodiversity loss from deforestation”, Nature, Vol. 535 No. 7610, pp. 144-147.

Becker, G.S. and Rubinstein, Y. (2004), "Fear and the response to terrorism: an economic analysis", University of Chicago Mimeo, Vol. 93 No. 1, pp. 1-10.

Berrino, A. (2011), Storia Del Turismo in Italia, Il Mulino, Bologna.

Bodosca, Ş., Gheorghe, G. and Nistoreanu, P. (2014), "Tourist consumption behavior before and after the crisis from 2008", Procedia Economics and Finance, Vol. 16, pp. 77-87.

Boehmer, T.K., DeVies, J., Caruso, E., van Santen, K.L., Tang, S., Black, C.L., Hartnett, K.P., Kite-Powell, A., Dietz, S., Lozier, M. and Gundlapalli, A.V. (2020), "Changing age distribution of the COVID-19 pandemic - United States, May-August 2020”, MMWR, Morbidity and Mortality Weekly Report, Vol. 69 No. 39, pp. 1404-1409.

Cerved (2019), L'impatto Del COVID-19 Sui Ricavi Delle Imprese Italiane, Cerved, Rome.

Cheng, M. (2016), "Sharing economy: a review and agenda for future research", International Journal of Hospitality Management, Vol. 57, pp. 60-70.

Cochrane, J. (2008), Asian Tourism: Growth and Change, Elsevier, London.

Corbisiero, F. (2020), "Sostenere il turismo: come il COVID-19 influenzerà il viaggio del futuro", Fuori Luogo. Rivista di Sociologia Del Territorio, Turismo, Tecnologia, Vol. 6 No. 2, pp. 69-79, doi: 10.6092/2723-9608/7177.

Corbisiero, F. and La Rocca, R.A. (2020), "Tourism on demand. A new form of urban and social demand of use after the pandemic event", Tema. Journal of Land Use, Mobility and Environment, Vol. 1, pp. 91-104, doi: 10.6092/1970-9870/6916.

Corbisiero, F., Paura, R. and Ruspini, E. (2020), "Il turismo dopo il coronavirus. Tecnologie, fragilità e crescenti responsabilità", FUTURI, Vol. 12, pp. 1-3.

Cowper, A. (2020), "COVID-19: are we getting the communications right?", BMJ, Vol. 368, p. 919, doi: 10.1136/bmj.m919.

Das, D., Sharma, S.K., Mohapatra, P.K. and Sarkar, A. (2007), "Factors influencing the attractiveness of a tourist destination: a case study", Journal of Service Research, Vol. 7 No. 1, pp. 103-134.

Dinev, K. (2020), "The return of domestic tourism”, Ibis World, 10/07/2020, available at: www.ibisworld. com/industry-insider/coronavirus-insights/the-return-of-domestic-tourism/ (accessed December 2020).

Ertz, M., Durif, F. and Arcand, M. (2019), “A conceptual perspective on collaborative consumption”, AMS Review, Vol. 9 Nos 1/2, pp. 27-41.

Florida, R. (2020), "The geography of the coronavirus", City Lab, available at: www.citylab.com/ equity/2020/04/coronavirus-spread-map-city-urban-density-suburbs-rural-data/609394 (accessed September 2020).

Goldstein, J.R. and Lee, R.D. (2020), "Demographic perspectives on the mortality of COVID-19 and other epidemics", Proceedings of the National Academy of Sciences, Vol. 117 No. 36, pp. 22035-22041.

Gössling, S., Scott, D. and Hall, C.M. (2020), "Pandemics, tourism and global change: a rapid assessment of COVID-19", Journal of Sustainable Tourism, Vol. 29 No. 1.

Gostin, L.O. and Lucey, D. (2015), "Middle East respiratory syndrome: a global health challenge", JAMA Online, Vol. 314 No. 8, pp. 1-3.

Hall, M.C. (2006), "Culinary tourism and regional development: from slow food to slow tourism?", Tourism Review International, Vol. 9 No. 4, pp. 303-306.

Hamari, J., Sjöklint, M. and Ukkonen, A. (2016), "The sharing economy: why people participate in collaborative consumption", Journal of the Association for Information Science and Technology, Vol. 67 No. 9, pp. 2047-2059. 
Haywood, K.M. (2020), “A post COVID-19 future - tourism re-imagined and re-enabled”, Tourism Geographies, Vol. 22 No. 3, pp. 599-609.

Ioannides, D. and Gyimóthy, S. (2020), "The COVID-19 crisis as an opportunity for escaping the unsustainable global tourism path", Tourism Geographies, Vol. 22 No. 3, pp. 624-632.

Post-pandemic tourism resilience

IPSOS (2020), Future4tourism, IPSOS, Milan.

Irwin, C.E. (2020), "Catching a break: accessibility, empathy, and COVID-19”, Qualitative Inquiry, doi: 10.1177/1077800420967889.

Ivkov, M., Blešić, I., Janićević, S., Kovačić, S., Miljković, Đ., Lukić, T. and Sakulski, D. (2019), "Natural disasters vs hotel industry resilience: an exploratory study among hotel managers from Europe”, Open Geosciences, Vol. 11 No. 1, pp. 378-390.

Jeuring, J.H.G. and Diaz-Soria, I. (2017), "Proximity and intraregional aspects of tourism", Tourism Geographies, Vol. 19 No. 1, pp. 4-8.

Jeuring, J.H.G. and Haartsen, T. (2017), "The challenge of proximity: the (un)attractiveness of near-home tourism destinations", Tourism Geographies, Vol. 19 No. 1, pp. 118-141.

Kaul, R. (1985), Dynamics of Tourism: A Trilogy, Sterling Publishing, New York, NY.

Kozul-Wright, R. and Barbosa, N. (2020), "Urgent need for swift economic response to coronavirus", Financial Times, 20 March.

La Rocca, R.A. (2013), "Tourism and city. Reflections about tourist dimension of smart city", TeMA Journal of Land Use, Mobility and Environment, Vol. 6 No. 2, pp. 201-214, doi: 10.6092/1970-9870/ 1483.

Lade, S.J., Steffen, W., De Vries, W., Carpenter, S.R., Donges, J.F., Gerten, D., Hoff, H., Newbold, T., Richardson, K. and Rockström, J. (2020), "Human impacts on planetary boundaries amplified by earth system interactions", Nature Sustainability, Vol. 3 No. 2, pp. 119-128.

Lapointe, D. (2020), "Reconnecting tourism after COVID-19: the paradox of alterity in tourism areas", Tourism Geographies, Vol. 22 No. 3, pp. 633-638.

Larsen, J. (2015), "Bicycle parking and locking: ethnography of designs and practices", Mobilities, Vol. 12 No. 1, pp. 1-23.

Lee, C.C. and Chen, C.J. (2011), "The reaction of elderly Asian tourists to avian influenza and SARS", Tourism Management, Vol. 32 No. 6, pp. 1421-1422.

Lombi, L. (2015), "La ricerca sociale al tempo dei big data: sfide e prospettive", Studi di Sociologia, Vol. 2, pp. 215-227.

Mahrt, M. and Scharkow, M. (2013), "The value of big data in digital media research", Journal of Broadcasting and Electronic Media, Vol. 57 No. 1, pp. 20-33.

Marino, R. (2020), "Intervista fuori luogo a Derrick de Kerckhove", Fuori Luogo. Rivista di Sociologia Del Territorio, Turismo, Tecnologia, Vol. 6 No. 2, pp. 133-140, doi: 10.6092/27239608/7285.

Milano, C., Novelli, M. and Cheer, J.M. (2019), “Overtourism and tourismphobia: a journey through four decades of tourism development", Planning and Local Concerns. Tourism Planning and Development, Vol. 16 No. 4, pp. 353-357.

Monaco, S. (2018), "Mobilità turistiche fuori dai luoghi. Forme e significati dei viaggi online per i giovani italiani”, Fuori Luogo. Rivista di Sociologia Del Territorio, Turismo, Tecnologia, Vol. 4 No. 2, pp. 91-104, doi: 10.6092/2723-9608/6979.

Monaco, S. (2019), "Mixed methods e e-research: frontiere possibili per lo studio delle hidden population”, Sociologia Italiana, Vol. 14, pp. 97-108, doi: 10.1485/AIS_2019/14_3443558.

Monaco, S. (2020), "Turismo in lockdown tra misure economiche e politiche simboliche", Rivista Trimestrale di Scienze Dell'amministrazione, Vol. 2, pp. 1-18, doi: 10.32049/RTSA.2020.2.19.

Moralli, M. and Allegrini, G. (2020), "Crises redefined: towards new spaces for social innovation in inner areas?”, European Societies, doi: 10.1080/14616696.2020.1841263. 
WHATT

13,3

Murji, K. and Picker, G. (2020), "Racist morbidities: a conjunctural analysis of the COVID-19 pandemic", European Societies, doi: 10.1080/14616696.2020.1825767.

Nilsson, J.H., Svärd, A., Widarsson, A. and Wirell, T. (2011), "CittáSlow: eco-gastronomic heritage as a tool for destination development", Current Issues in Tourism, Vol. 14 No. 4, pp. 373-386.

Noor, S., Guo, Y., Shah, S.H.H., Fournier-Viger, P. and Nawaz, M.S. (2020), “Analysis of public reactions to the novel coronavirus (COVID-19) outbreak on twitter", Kybernetes, doi: 10.1108/K-05-20200258.

OCSE (2020), OECD Tourism Trends and Policies 2020, OECD Publishing, Paris.

Page, S.J. and Connell, J. (2020), Tourism: A Modern Synthesis, Routledge, New York, NY.

Pagliara, F., Mauriello, F. and Garofalo, A. (2017), "Exploring the interdependences between high speed rail systems and tourism: some evidence from Italy", Transportation Research Part A: Policy and Practice, Vol. 106, pp. 300-308.

Papa, R. and Fistola, R. (2016), Smart Energy in the Smart City Urban Planning for a Sustainable Future, Springer International Publishing, New York, NY.

Rab, L. and Kettler, K. (2020), "Perspective of sustainable development in post-pandemic world: surveillance capitalism and hopes", Society Register, Vol. 4 No. 2, pp. 159-166.

Röcker, C. (2010), “Why traditional technology acceptance models won't work for future information technologies", World Academy of Science, Engineering and Technology, Vol. 65, pp. 237-243.

RTE (2020), "How the coronavirus may hit the tourism industry", 03 March, available at: www.rte. ie/brainstorm/2020/0303/1119857-coronavirus-tourism-ireland/ (accessed 24 September 2020).

Seraphin, H. and Dosquet, F. (2020), "Mountain tourism and second home tourism as post COVID-19 lockdown placebo?", Worldwide Hospitality and Tourism Themes, Vol. 12 No. 4, pp. 485-500.

Sigala, M. (2020), "Tourism and COVID-19: Impacts and implications for advancing and resetting industry and research", Journal of Business Research, Vol. 117, pp. 312-321.

Tembo, D. (2020), "The road now less travelled”, International Trade Forum, Vol. 1, pp. 3-13.

Unimpresa (2020), Coronavirus, Unione nazionale di Imprese, Rome.

UNWTO (2019), International Tourism Highlights, United Nations World Tourism Organization, Madrid.

UNWTO (2020a), Tourism and COVID-19, United Nations World Tourism Organization, Madrid.

UNWTO (2020b), World Tourism Barometer and Statistical Annex (August/September 2020), United Nations World Tourism Organization, Madrid.

Urry, J. and Larsen, J. (2011), The Tourist Gaze 3.O, Sage, London.

Urry, J. and Sheller, M. (2006), “The new mobilities paradigm”, Environment and Planning A: Economy and Space, Vol. 38 No. 2, pp. 207-226.

Vishal, V.J. and Aakriti, S. (2020), "Impact of COVID-19 pandemic on hospitality sector and it's revival post vaccine: a review”, Journal of Business and Social Science Review, Vol. 1 No. 7 , pp. 53-64.

WTTC (2020a), Global Economic Impact and Trends, World Travel and Tourism Council, London.

WTTC (2020b), To Recovery and beyond: The Future of Travel and Tourism in the Wake of COVID-19, World Travel and Tourism Council, London.

Yu, M., Li, Z., Yu, Z., He, J. and Zhou, J. (2020), "Communication related health crisis on social media: a case of COVID-19 outbreak", Current Issues in Tourism, doi: 10.1080/13683500.2020.1752632. 


\section{About the authors}

Fabio Corbisiero is Associate Professor. His research draws from the literatures on urban sociology, tourism studies, gender and LGBT studies, and it focuses on understanding how the spatial organization creates and reproduces inequality for vulnerable social categories. Fabio Corbisiero's current research agenda investigates (1) how the urban context, particularly the experience of European cities, determines the life chances of vulnerable people; (2) how tourism forms emerge and evolve in urban contexts; (3) how places and geographies structure socio-economic opportunity in Italy and elsewhere. He is Coordinator of Osservatorio LGBT and OUT (Osservatorio Universitario sul Turismo) of the University of Naples Federico II.

Salvatore Monaco is a postdoctoral researcher in sociology at the Faculty of Education, Free University of Bozen (Italy), where he is adjunct professor of "Genders, Identities and Territories." He achieved $\mathrm{PhD}$ degree in "Social Sciences and Statistics" at the Department of Social Sciences, University of Naples Federico II. He has been a researcher of Osservatorio LGBT and OUT (Osservatorio Universitario sul Turismo) of the University of Naples Federico II for several years. His research interests include tourism, technologies and territories with particular focus on identities, genders, sexual orientations and generations. Salvatore Monaco is the corresponding author and can be contacted at: salvatore.monaco@unibz.it

For instructions on how to order reprints of this article, please visit our website: www.emeraldgrouppublishing.com/licensing/reprints.htm Or contact us for further details: permissions@emeraldinsight.com 